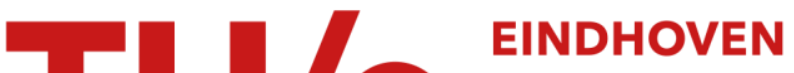

\section{Semiconductor waveguide device for picosecond pulse amplification and spectral shaping at $1560 \mathrm{~nm}$}

\section{Citation for published version (APA):}

Heck, M. J. R., Bente, E. A. J. M., Barbarin, Y., Fryda, A., Jung, H. D., Oei, Y. S., Nötzel, R., Lenstra, D., \& Smit, M. K. (2007). Semiconductor waveguide device for picosecond pulse amplification and spectral shaping at 1560 $\mathrm{nm}$. In Proceedings of the 2007 Conference on Lasers and Electro-Optics (CLEO 2007) 6 - 11 May 2007, Baltimore, Maryland, USA (pp. CTuFF2-1/2). Institute of Electrical and Electronics Engineers.

https://doi.org/10.1109/CLEO.2007.4452975

DOI:

10.1109/CLEO.2007.4452975

Document status and date:

Published: 01/01/2007

\section{Document Version:}

Publisher's PDF, also known as Version of Record (includes final page, issue and volume numbers)

\section{Please check the document version of this publication:}

- A submitted manuscript is the version of the article upon submission and before peer-review. There can be important differences between the submitted version and the official published version of record. People interested in the research are advised to contact the author for the final version of the publication, or visit the $\mathrm{DOI}$ to the publisher's website.

- The final author version and the galley proof are versions of the publication after peer review.

- The final published version features the final layout of the paper including the volume, issue and page numbers.

Link to publication

\section{General rights}

Copyright and moral rights for the publications made accessible in the public portal are retained by the authors and/or other copyright owners and it is a condition of accessing publications that users recognise and abide by the legal requirements associated with these rights.

- Users may download and print one copy of any publication from the public portal for the purpose of private study or research.

- You may not further distribute the material or use it for any profit-making activity or commercial gain

- You may freely distribute the URL identifying the publication in the public portal.

If the publication is distributed under the terms of Article 25fa of the Dutch Copyright Act, indicated by the "Taverne" license above, please follow below link for the End User Agreement:

www.tue.nl/taverne

Take down policy

If you believe that this document breaches copyright please contact us at:

openaccess@tue.nl

providing details and we will investigate your claim. 


\title{
Semiconductor Waveguide Device for Picosecond Pulse Amplification and Spectral Shaping at $1560 \mathrm{~nm}$
}

\author{
M.J.R. Heck, E.A.J.M. Bente, Y. Barbarin, A. Fryda, H.D. Jung, Y.S. Oei, \\ R. Nötzel, D. Lenstra and M.K. Smit \\ COBRA Research Institute, Technische Universiteit Eindhoven, Postbus 513, 5600 MB Eindhoven, The Netherlands \\ E-mail: m.heck@tue.nl
}

\begin{abstract}
Amplification of picosecond pulses with greatly reduced amplified spontaneous emission compared to a standard semiconductor amplifier (up to 30dB) and a large increase in coherent spectral bandwidth is demonstrated in devices we have fabricated. (C)2007 Optical Society of America

OCIS codes: (130.5990) Semiconductors; (190.4390) Nonlinear optics, integrated optics
\end{abstract}

\section{Introduction}

Pulsed lasers with a coherent broad optical spectrum are attractive sources for use in e.g. arbitrary waveform generators [1] and optical code-division multiple-access (O-CDMA) systems [2]. Such systems can be realized on a single photonic integrated circuit when semiconductor mode-locked lasers (MLLs) are used as the pulsed source. Nowadays monolithic MLLs are able to produce pulses with durations down to 1-2ps, having a corresponding spectral width of up to 2-3nm [3]. To increase the optical bandwidth of picosecond pulses further, amplification and highly non-linear fibers are often used. In a photonic integrated circuit a semiconductor optical amplifier (SOA) is an option, though at the expense of adding amplified spontaneous emission (ASE) to the pulses. Also the broadening that can be achieved is limited. In this paper we present our device named IRIS [4] which we have designed to add bandwidth to an optical picosecond pulse, for applications as mentioned above. We experimentally compare the performance of a number of configurations of the IRIS device with an SOA of the same length.

\section{IRIS device}

The IRIS device consists of a series of equal pairs of one SOA section and one saturable absorber (SA) section, as schematically depicted in Fig. 1(a). Its most important feature is that the saturation energy of the SA is lower than the saturation energy of the SOA. As a result a short pulse that propagates through the device will first saturate the SA and only after that the SOA, much like in passive mode-locking [5]. The IRIS devices have been realized using InP/InGaAsP bulk gain material, and operate at wavelengths in the region of $1.55 \mu \mathrm{m}$. The sequence of SOAs and SAs is fabricated by etching a shallow ridge waveguide of $2 \mu \mathrm{m}$ width in the bulk gain material. To suppress lasing, the waveguide is oriented at the Brewster angle for the fundamental mode with the facets which have also been antireflection coated. To create electrical isolation between the SOAs and SAs, the most highly doped part of the pcladding layers is etched away using a dry RIE etch process. The isolation section between the SOA and SA has a length of $10 \mu \mathrm{m}$ (shorter SAs) to $15 \mu \mathrm{m}$ (longer SAs). Two gold metal pads alternately contact the waveguide sections to create two common contacts for the SOAs and SAs respectively (Fig. 1(b)). Amplification and absorption are realized by a forward or reverse electrical bias of the diode respectively. We have designed and realized a number of different device configurations with $20 \mathrm{SOA} / \mathrm{SA}$ pairs and varying length ratio between the SOA and SA. We have added $2 \mathrm{~mm}$ long SOAs on the same chip for reference purposes. The fabrication technology of the IRIS device is fully compatible with the technology to fabricate MLLs as presented in [6]. This allows for further integration of the MLLs with the IRIS device.

(a)

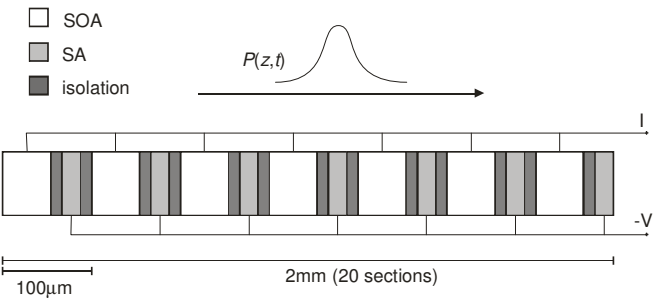

(b)

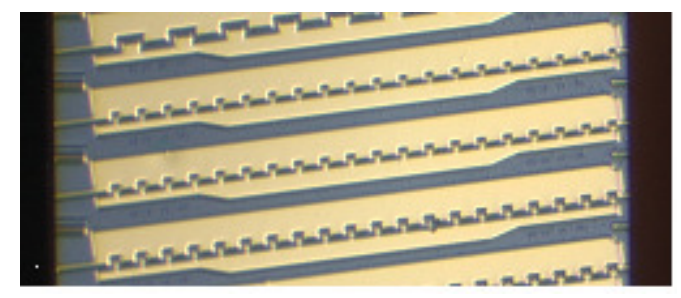

Fig. 1. (a) Schematic overview of the IRIS configuration used in the measurements. An input pulse (denoted by $\mathrm{P}(\mathrm{z}, \mathrm{t})$ ) arrives from the left, entering an SOA and exiting from the right-hand side. The ratio of the SOA and SA length within the $100 \mu \mathrm{m}$ section (only 7 out of 20 shown) is varied. Common contacts are used for applying the injection current I and the reverse bias V. (b) Photograph of the realized devices, showing different configurations. 


\section{CTuFF2.pdf}

\section{Experimental results}

Spectra of short pulses that have propagated through one of several designs of IRIS devices have been measured. The TE polarized input pulses have a peak power of approximately $0.08 \mathrm{~W}$, a duration of $2.5 \mathrm{ps}$ and a repetition rate of $10 \mathrm{GHz}$. Looking at the spectra, two important observations are made. First the attainable spectral broadening is larger for the IRIS devices (up to $4 \mathrm{~nm}$, Fig. 2(a)) for the shorter SA lengths $(60 \mu \mathrm{m} / 10 \mu \mathrm{m}$ and $55 \mu \mathrm{m} / 15 \mu \mathrm{m}$ configuration) than for an equally long SOA $(3 \mathrm{~nm})$. The reason is that the temporal broadening of the pulse is limited due to the interplay between the pulse and the SOA and SA, much like in passive mode-locking. As a result the self-phase modulation is larger than in the SOA. Secondly, by increasing the reverse bias voltage on the SA sections the modulation depth in the spectrum can be decreased (Fig. 2(b)). This feature of the spectrum makes the IRIS device more suitable for applications as mentioned above. A spectrum with less spectral structure requires less intensity modulation of the separate spectral components in a subsequent pulse shaping device.

The output pulse energy from the IRIS devices is only $2 \mathrm{~dB}$ lower than the output pulse energy from an SOA (Fig. 3(a)). However the ASE is strongly reduced in the IRIS devices, up to three orders of magnitude (Fig. 3(b)). The pulses have a large peak power compared to the ASE power level and therefore saturate the SAs as opposed to the ASE. The SAs become almost transparent for the pulse. Between the pulses the SA can recover and the ASE will be absorbed. This makes the IRIS device a very promising short pulse amplifier.

It can be concluded that the increased spectral broadening, the strongly reduced ASE levels and the compatibility of the fabrication technology, make that the IRIS device is most suitable for integration on a chip in more complex systems where a large optical bandwidth is needed, such as O-CDMA systems.

(a)

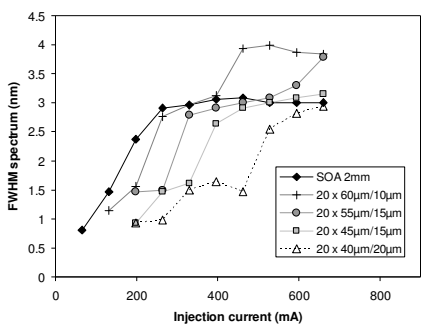

(b)

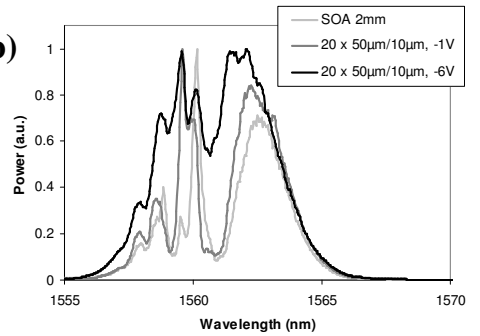

Fig. 2. (a) Measured spectral widths (FWHM) for different IRIS configurations (20 sections $\times$ SOA/SA length). The applied reverse bias on the SAs is $-1 \mathrm{~V}$. (b) Normalized output pulse spectra showing decreased modulation depth for higher reverse bias voltage of $-6 \mathrm{~V}$. I=660mA.

(a)

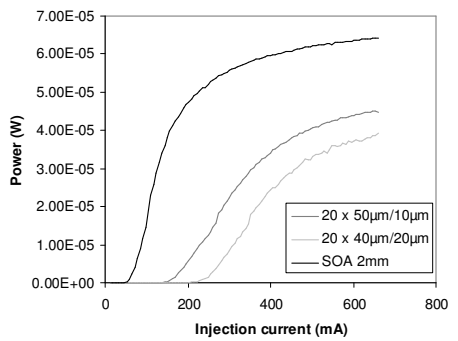

(b)

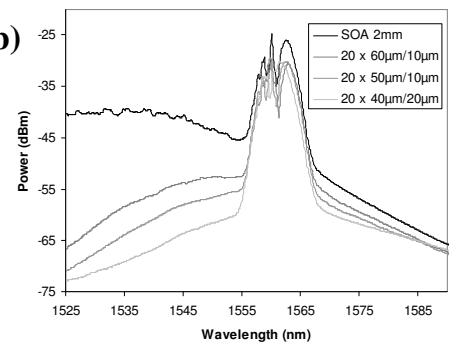

Fig. 3. (a) Measured in-fiber output power for different IRIS configurations. The injection current is supplied by a pulsed source, using $300 \mathrm{~ns}$ pulses and $1 \%$ duty cycle. Lensed fibers are used for outcoupling. (b) Optical output spectra including the ASE background for an injection current of $660 \mathrm{~mA}$.

This research is supported by the Towards Freeband Communication Impulse of the technology program of the Dutch Ministry of Economic Affairs and by the Dutch NRC-Photonics program.

\section{References}

[1] K. Takiguchi, K. Okamoto, T. Kominato, H. Takahashi and T. Shibata, "Flexible pulse waveform generation using silica-waveguide-based spectrum synthesis circuit," Electron. Lett., vol. 40, no. 9, pp. 537-538, 2004

[2] C. Ji, R.G. Broeke, Y.Du, J. Cao, N. Chubun, P. Bjeletich, F. Olsson, S. Lourdudoss, R. Welty, C. Reinhardt, P.L. Stephan and S.J.B. Yoo, "Monolithically integrated InP-based photonic chip development for O-CDMA systems," IEEE J. Select. Topics Quantum Electron., vol. 11, no. 1, pp. 66-77, Jan./Feb. 2005

[3] R. Kaiser, B. Hüttl, H. Heidrich, S. Fidorra, W. Rehbein, H. Stolpe, R. Stenzel, W. Ebert, and G. Sahin, "Tunable monolithic mode-locked lasers on InP with low timing jitter," IEEE Photon. Technol. Lett., vol. 15, no. 5, pp. 634-636, May 2003.

[4] M.J.R. Heck and E.A.J.M. Bente, NL patent application

[5] M.J.R. Heck, E.A.J.M. Bente, Y. Barbarin, D. Lenstra and M.K. Smit, "Simulation and design of integrated femtosecond passively modelocked semiconductor ring lasers including integrated passive pulse shaping components," IEEE J. Quantum Electron., vol. 12, no. 2, Mar.-Apr. 2006.

[6] Y. Barbarin, E.A.J.M. Bente, M.J.R. Heck, Y.S. Oei, R. Nötzel and M.K. Smit, "Characterization of a 15 GHz integrated bulk InGaAsP passively modelocked ring laser at $1.53 \mu \mathrm{m}$," accepted for publication in Optics Express 